\title{
H. SALIM M. ALBAAR \\ ULAMA DAN TOKOH PENDIDIKAN DI TERNATE
}

\section{Scholars and Education Prominent Figure in Ternate}

\author{
Muhammad As'ad \\ Balai Penelitian dan Pengembangan Agama Makassar \\ Jl. A.P.Pettarani No. 72 Makassar \\ Email: malitbang@yahoo.com
}

Naskah diterima tanggal 10 Juni 2014. Naskah direvisi tanggal 7 Agustus 2014. Naskah disetujui tanggal 11 Agustus 2014.

\begin{abstract}
Abstrak
Tulisan ini merupakan hasil penelitian di Kota Ternate berkaitan dengan Biografi Ulama di Ternate, H.Salim M. Albaar. Ia adalah seorang ulama Ternate (1964-2012) keturunan Arab yang dalam silsilah keturunannya memiliki persambungan sampai pada Rasulullah. Ternate adalah salah satu dari empat kerajaan di Maluku Utara yang terkenal sejak dahulu dalam perdagangan internasional karena rempah-rempahnya. Kerajaan Ternate adalah salah satu Kerajaan Islam terkenal dalam pengembangan Islam di Nusantara. Keberadaan ulama keturunan Arab di daerah ini memiliki peran penting dalam pengembangan Islam. Habib Salim Albaar yang pernah mondok pada Pesantren Al Khaerat Palu merupakan ulama, tokoh pendidik, dan politikus yang berjasa di Ternate.
\end{abstract}

Kata kunci: ulama, kota Ternate, $\mathrm{Al}$ Khaerat, memimpin madrasah

\begin{abstract}
This paper is the result of research conducted in the city of Ternate related to Biography of Ulama in Ternate. Drs.H.Salim M. Albaar was a scholar of Ternate (1964-2012) Arab descent in his genealogy has a linkage to the Prophet Muhammad Saw. Ternate is one of the four kingdoms in North Maluku are very famous as early as international trade because of its spices. The kingdom of Ternate is one of the famous Islamic kingdom in the development of Islam in the archipelago. The existence of Arab descent Scholars in Ternate area has an important role in the development of Islam. Habib Salim Albaar who had studied at Pesantren al Khaerat Palu is a scholars,educator prominent figure, and politicians who was deserving in Ternate.
\end{abstract}

Keywords: scholars (ulama), city of Ternate, Al Khaerat, leading madrasah

\section{PENDAHULUAN}

$\mathrm{K}$ erajaan Ternate adalah salah satu dari empat kerajaan utama di Maluku Utara yang dikenal dengan Moloku Kie Raha (empat kerajaan di Maluku), yaitu: Ternate, Tidore, Bacan, dan Jailolo. Maluku Utara yang pada masa dahulu dikenal dengan Maluku adalah daerah yang masyhur di seantero dunia karena kesemerbakan aroma rempahnya. Daerah ini merupakan penghasil rempah, terutama cengkeh dan pala yang saat itu merupakan komoditi incaran para komunitas niaga dunia. M. Saleh Putuhena mengemukakan bahwa pedagang yang datang pertama kali di Maluku adalah para pedagang Melayu dan Jawa.
Dari tangan mereka inilah cengkeh dapat dibeli oleh para pedagang Arab, India, Persia, dan Cina (Darmawijaya, 2010: 115).

Keharuman komoditas ini semakin semerbak sehingga pedagang-padagang yang semula mengenalnya lewat pedagang Melayu dan Jawa berusaha mengunjungi Maluku secara langsung. Komoditi cengkeh dan pala telah memikat para pedagang asal Arab untuk berkompetisi dalam arus perdagangan bersama dengan pedagang asal India dan Cina. Para pedagang asal Arab Islam pada abad pertama hijriyah telah membawa Islam ke Ternate (Fakhriati dkk, 2010: 1).

Kedatangan orang-orang Arab yang beragama Islam di Maluku menandai kedatangan agama Islam 
di daerah ini. Dengan demikian, dapat dikatakan kedatangan Islam di Maluku sejak dahulu kala. Bahkan, cikal bakal keempat kerajaan di Maluku yang dikenal Kie Raha adalah orang Arab Islam. Tradisi lisan yang dijadikan rujukan para penulis mengemukakan hal itu. Para penguasa Moloku Kie Raha adalah keturunan Jafar Shadiq yang sampai di Maluku pada hari Senin 6 Muharram tahun 643 H/1250 Masehi dan kemudian menikah dengan seorang putri bernama Nur Sifa. Dari pernikahan ini, mereka dikaruniai delapan orang anak, empat putra dan empat putri. Keempat putra Ja'far Sahadiq inilah yang menjadi raja di empat kerajaan di Maluku. Mereka itu adalah: 1. Kaicil Buka adalah raja di Bacan, 2. Darajati adalah raja di Jailolo, 3. Sahajati adalah raja di Tidore, dan Masyhur Malamo raja di Ternate (Darmawijaya, 2010: 116117). Keberadaan orang Islam di Ternate bahkan adanya raja keturunan orang Islam tidak menjamin penyebaran dan pelembagaan Islam dalam masyarakat apabila ulama sebagai tokoh Islam tidak mengambil peranan dalam masyarakat.

Penyebaran dan pelembagaan Islam di kerajaan Ternate baru terjadi pada pertengahan abad ke-15. Sejak diterimanya agama Islam di Kerajaan Ternate pada abad ke-15 oleh Kolano Kaicil Marhum (14561486), maka Islam dianut semua lapisan masyarakat, bahkan diserap ke dalam kelembagaan kerajaan. Pranata-pranata Islam dipadukan dengan lembagalembaga adat dan tradisi rakyat Ternate (Fakhriati dkk, 2010: 3-4).

Marhum masuk Islam setelah mendapat seruan dakwah dari seorang pedagang asal Minangkabau yang juga murid Sunan Giri, yaitu Datu Maulana Husain yang datang ke Ternate pada tahun 1465. Maulana Husain adalah seorang muballig besar pada masanya, yang memiliki pengetahuan Islam yang luas dan dalam (ulama), ahli dalam membaca ayat-ayat $\mathrm{Al}$ Qur'an, dan mahir dalam membuat kaligrafi Arab (Darmawijaya, 2010: 119-120).

Ulama merupakan tokoh penting dalam masyarakat Islam di Indonesia. Bahkan secara umum, ulama merupakan faktor dinamis yang telah membawa pengaruh penting dalam dinamika masyarakat Islam. Apabila kita ingin mengetahui dinamika Islam, maka kita harus melihat bukan kepada masyarakat kebanyakan (massa) melainkan kepada pemimpin Islam atau ulama (Abd. Kadir Ahmad, 2008: 4)

Perkembangan dan dinamika Islam di Kerajaan Ternate dalam melewati berbagai kurun waktu tidak terlepas dari keberadaan ulama dari dahulu sampai sekarang. Salah seorang ulama yang terkenal di Ternate akhir-akhir ini adalah H. Salim M. Al Baar. Bagaimana lingkungan masyarakat yang mengitarinya, bagaimana kehidupan pribadi dan keluarganya, dan bagaimana peran yang dimainkan dalam kehidupan masyarakat Ternate, menjadi sorotan dalam tulisan ini.

\section{METODE PENELITIAN}

Penelitian ini merupakan penelitian deskriptif kualitatif yang dilaksanakan di Kota Ternate, Propinsi Maluku Utara dengan menggunakan teknik pengumpulan data: Observasi terhadap lingkungan masyarakat sekitar ulama yang diteliti, terutama kehidupan keagamaannya; Wawancara dengan informan yang relevan, memiliki informasi berharga tentang penelitian. Informan berasal dari keluarga atau kerabat (sasaran penelitian), tokoh masyarakat, dan anggota masyarakat lainnya; Studi pustaka dan dokumen yang berkaitan dengan penelitian.

Karena penelitian ini merupakan peneltian kualitatif deskritif, maka analisis data dilakukan dengan analisis kualitatif deskriptif dalam bentuk kategorisasi data dan menghubungkan data yang relevan kemudian dilakukan narasi.

\section{Tinjauan Pustaka}

Kata ulama berasal dari bahasa Arab yang diserap dalam bahasa Indonesia. Dalam kamus bahasa Arab Al Munjid fi al Lugah wal A'lam, kata ulama merupakan bentuk jamak (plural) dari kata aliem yang bermakna orang yang memiliki pengetahuan (Anonim, 1986). Kata alim dalam bahasa Indonesia bermakna berilmu (terutama dalam hal agama Islam), saleh. Sedang ulama bermakna orang yang ahli dalam hal atau dalam pengetahuan agama Islam (Tim Penyusun Kamus Pusat pembinaan dan Pengembangan Bahasa, 1993).

CerylGlassemengemukakan pengertian ulama dengan mengatakan bahwa kata ulama merupakan bentuk jamak dari alim yang berarti terpelajar, cendekiawan. Kata ini bermakna orang-orang yang diakui sebagai cendekiawan atau sebagai pemegang otoritas pengetahuan agama Islam. Mereka adalah para imam masjid-masjid besar (agung), para hakim (agama Islam), dosen-dosen agama pada universitas (perguruan tinggi Islam), dan yang secara umum ia merupakan lembaga kelompok terpelajar atau kalangan cendikiawan keislaman yang memiliki hak penentu atas permasalahan keagamaan (Islam) (Glasse, 2002: 417). 
Penyerapan kata ulama dalam istilah Indonesia terjadi pergeseran makna. Kata ulama dipergunakan sebagai kata tunggal (bukan jamak). Untuk menunjukkan kata jamaknya dengan dua cara, yaitu: ditambah di depannya kata para (para ulama) atau dijadikan kata ulang (ulama-ulama). Dalam pemakaiannya terkadang kata alim dan kata ulama digandengkan menjadi kata majemuk (alim-ulama). Istilah ulama dalam penggunaannya hanya digunakan untuk para ahli agama Islam saja, meskipun pada masa dahulu secara politik Soekarno, presiden pertama Indonesia telah menggunakannya untuk para ahli agama lainnya. Sebagai indikasinya dalam keanggotaan MPRS terdapat golongan ulama yang meliputi Ulama Islam, Ulama Khatolik, Ulama Kristen, serta Ulama Hindu dan ulama Budha (Ismuha, 1983:3).

Dengan demikian, ulama adalah seseorang yang mempunyai ilmu pengetahuan agama Islam yang luas serta mendapat pengakuan masyarakat. Pengakuan tersebut didasarkan pada akhlak yang mulia, keteladanan, dan aktivitas sosial mereka dalam menjalankan amar mảruf nahi munkar.

Menurut Horikoshi, fungsi ulama yang terpenting adalah peran ortodoks dan tradisional mereka sebagai penegak keimanan dengan cara mengajarkan doktrin-doktrin keagamaan dan memelihara amalan-amalan keagamaan ortodoks di kalangan umat Islam (Turmudi, 2003: 29)

Kajian tentang ulama telah banyak dilakukan, di antaranya: Bibit Suprapto dalam bukunya "Ensiklopedi Ulama Nusantara Riwayat Hidup, Karya dan Sejarah Perjuangan 157 Ulama Nusantara". Ada 157 orang ulama termuat di dalamnya, dari berbagai daerah di Nusantara, mulai dari ulama yang tergolong periode awal sampai pada ulama yang masih hidup dan berkiprah di tengah masyarakat baik dalam bidang pendidikan, pembinaan umat, ekonomi, dan dalam memperjuangkan republik Indonesia. (Suprapto, 2009).

Kajian lain ialah yang diprakarsai oleh Majelis Ulama Indonesia Sulawesi Selatan untuk menyusun biografi beberapa ulama di Sulawesi Selatan. Hasil kajian ini dituangkan dalam buku yang berjudul "Ulama Sulawesi Selatan, Biografi Pendidikan dan Dakwah". Dalam kajian ini terlibat beberapa penulis untuk menyusun biografi 14 orang dari ulama-ulama ternama di Sulawesi Selatan, bahkan di antaranya terkenal di tingkat nasional, seperti AG. H. Muhammad As'ad dan AG. H. Ambo Dalle (keduanya sudah termuat dalam buku Ensiklopedi Ulama Nusantara yang telah dikemukakan).
Kajian tentang ulama Sulawesi Selatan juga telah dilakukan oleh Abd. Kadir Ahmad dalam disertasinya yang kemudian dipulikasikan dengan judul "Ulama Bugis". Dalam buku ini dikemukakan juga biografi AG.H.Daud Ismail dan 12 ulama lainnya yang kebanyakan merupakan murid-murid beliau (Ahmad, 2008).

\section{PEMBAHASAN \\ Ulama Kota Ternate}

Marhum adalah Kolano Ternate yang pertama masuk Islam. Ia menganut Islam setelah mendapatkan ajakan dakwah dari seorang pedagang asal Minangkabau, murid Sunan Giri, yaitu Datu Maulana Husain yang datang ke Ternate pada tahun 1465. Datuk Maulana Husain memiliki pengetahuan Islam yang luas dan dalam serta mempunyai keterampilan membuat kaligrafi Arab serta mahir melantunkan Al Qur'an. Pada tahun 1486 Marhum mangkat dan dimakamkan menurut syariat Islam. Setelah wafat Marhum digantikan oleh putranya Zainal Abidin. Setelah berkuasa, ia mengganti gelar kolano dengan sultan (Darmawijaya, 2010: 119120).

Sultan Zainal Abidin pernah menimba ilmu di Gersik, Pulau Jawa pada Sunan Giri, dan sekembali dari Jawa, ia juga membawa beberapa ulama yang kemudian berdomisili di sebuah tempat di Ternate bernama falajawa (rumah Jawa). Ia juga mendirikan tempat pendidikan agama dan mewajibkan pegawai daerah untuk belajar syariat Islam di Ternate. ( Fakhriati dkk, 2010: 79-80). Sultan Zainal Abidin belajar pada Sunan Giri pada tahun 1495, kemudian pergi ke Malaka memperdalam Islam. Malaka pada saat itu dipimpin oleh Sultan Alauddin Riayat Syah dan merupakan pusat perdagangan dan penyebaran Islam terbesar di Asia Tenggara (Darmawijaya, 2010:121).

Sultan Zainal Abidin tidak hanya melakukan perubahan dalam masalah gelar, tetapi juga melakukan beberapa perubahan yang mendasar, yaitu: Pertama, menjadikan Islam sebagai agama resmi kerajaan dan sejak itu menjadi kesultanan. Kedua, membentuk lembaga kesultanan yang baru, yaitu Jolebe atau Bobato Akherat. Tugas Jolebe adalah membantu dalam masalah keagamaan. Jolebe terdiri seorang kalem (qadhi), empat orang imam, delapan orang khatib, dan enam belas orang moding yang membantu sultan menjalankan fungsi-fungsi keagamaan dan syariat Islam. Ketiga, Menempatkan seorang sulatan sebagai pembina agama Islam atau Amir ad-Din yang membawahi jobele. Perubahan yang dilakukan oleh Sultan Zainal Abidin ini juga 
diikuti oleh kesultanan-kesultanan yang ada di Moluku Kei Raha lainnya (Darmawijaya, 2010: 119120).

Di antara ulama di Ternate yang dapat diinventarisir pada saat penelitian ini (2013) ada yang sudah meninggal (almarhum) dan ada yang masih hidup, yaitu: Yang almarhum: 1. Habib Muhammad bin Abd. Rahman Albaar (wafat 1929 M), 2. Habib Hasim bin Muhammad Albaar (Wafat 3-2-1974), 3. Habib Mustafa bin Muhammad Albaar (Wafat $1981 \mathrm{M}$ ), 4. Habib Mutachhar bin Muhammad Albaar (Wafat 30-8-1997), 5. Habib Drs. Salim bin Mustafa Albaar (wafat 20-10- 2012), 6. Drs.H. Yusuf Abd. Rahman, 7. Hj. Syarif Sahafin, 8. Drs.Abjan Yahya, 9. Abd.Rahman Assagaf, 10. Mustafa bin Syekh Abubakar, dan 11. Aqil bin Syekh Abubakar. Sementara ulama yang Masih Hidup antara lain: 1. Drs.H.Bujang Hasan (Ketua MUI Maluku Utara), 2. Drs.H.Ibrahim, 3. Muhammad, M.Pdi, 4. DR. Yamin Haddad, 5. DR. Samlan, 6. Drs.Ziharuddin A. Lubis, 7. H.Abd.Gasni Kasuba (Wagub Malut), 8. H.Yahya Abdurrahman Mispah, 9. Muh.Said Abdullah, 10. Ali Albaar, 11. Habib Abubakar bin Hasan Al Attas, dan 12. Habib Bagir.

\section{Kehidupan H. Salim M. Albaar}

Salim M. Albaar yang lahir di Kota Ternate pada tanggal 17 Desember $1946 \mathrm{M}$ ada-lah putra dari pasangan Habib Mustafa bin Habib Muhammad bin Habib Abd. Rahman dengan Aminah Al Habsyi. Habib Mustafa Albaar telah menikah dua kali, yaitu pertama dengan Jahrah Albaar dan kedua dengan Aminah Al Habsyi. Perkawinan kedua dilakukan setelah isteri pertama meninggal dunia. Dari isteri pertama, Habib Mustafa Albaar dikarunia tiga orang anak, dua putri dan seorang putra, yaitu: Mastura, Maryam, dan Muhammad. Yang masih hidup sampai penelitian ini (2013) adalah Masturah. Dari isteri kedua memperoleh 10 anak, tiga di antaranya meninggal saat kecil. Tujuh anak lainnya (empat putri dan tiga putra) yaitu: Talhah, Hindun, Aidit, Salim, Hasan, Fatmah, dan Arfah. Yang masih hidup sampai penelitian ini tiga orang, yaitu: Talhah, Fatmah, dan Arfah.

Kakek Salim Albaar, Muhammad bin Abdurrahman Albaar, seorang ulama terekenal di kalangan masyarakat Maluku Utara. Ia menurunkan ulama-ulama yang berkiprah di daerah ini. Ia kawin 10 kali, antara lain dengan Syarifah Salma al Habsyi melahirkan Hasyim Albaar. Dengan Ummi (Lim Seng, keturunan Cina) melahirkan Mustafa Albaar, bapak dari Salim M. Albaar.
Salim M. Albaar kawin dengan tambatan hatinya bernama Fauziah pada tanggal 26 Oktober 1980. Fauziah adalah anak perempuan dari pasangan Feray bin Abd.Azis dan Masad. Fauziah binti Faray adalah seorang perempuan yang digolongkan sebagai seorang ulama perempuan di Ternate.

Jenjang pendidikan yang dilalui ustazah Fauziah adalah sekolah umum dan madrasah. Ia tamat SD tahun 1958, SMP tahun 1961, dan SMA tahun 1964 di Ternate, namun keinginannya untuk memperdalam ilmu agama menyebabkan ia tidak melanjutkan pendidikannya di perguruan tinggi umum, bahkan ia kembali ke bangku sekolah dasar, yaitu duduk pada kelas III Madrasah Ibtidaiyah Al Khaerat yang sudah terbuka di Ternate. Setelah tamat madrasah ini tahun 1967, ia melanjutkan pendidikannya ke Madrasah Muallimin 4 tahun yang berada di bawah naungan $\mathrm{Al}$ Khaerat Ternate dan tamat tahun 1967. Setelah tamat madrasah Muallimin Al Khaerat, ia mengabdikan dirinya pada Al Khaeraat, yaitu sebagai guru Ibtidaiyah. Sambil mengajar pada madrasah ini, karena tingkat Aliyah telah dibuka oleh Al Khaerat maka ia melanjutkan pendidikannya ke madrasah Aliyah. Pengabdiannya di Al Khaerat cukup lama karena ia mengundurkan diri sebagai pengajar sekitar tahun 1993. Ia mengajar sebagai guru swasta, bukan PNS. Ia sering diajak untuk menjadi guru PNS tetapi ditolaknya karena alasan, sebagai guru negeri terikat dan dapat dimutasi sewaktu-waktu. Ia pun berhenti mengajar di Al Khaerat karena pertimbangan kesibukannya mengurus keluarga, terutama mengurus Habib. Menurutnya urusan keluarga adalah paling utama, baik sebagai isteri maupun sebagai ibu dari anakanaknya. Namun berhenti dari kegiatan mengajar di madrasah bukan berarti berhenti dari kesibukan di luar rumah tangganya. Ia dipercayakan sebagai ketua organisasi Wanita $\mathrm{Al}$ Khaerat dan embannya sampai tahun 2008, periode yang lalu. Walaupun ia berhenti sebagai ketua tetapi pengabdiannya terhadap organisasi wanita $\mathrm{Al}$ Khaerat tidak berhenti dan ia dipercaya sebagai penasehat organisasi kewanitaan ini.

Hanya satu tahun setelah perkawinan Salim M. Albaar dengan isteri tercintanya Ustazah Fauziah, keduanya dikaruniai seorang putra. Tepatnya tanggal 24 November 1981, Ustazah Fauziah melahirkan bayi lelaki yang diberinya nama Idrus. Pada tanggal 03 Juni 1983, pasangan ini dikaruniai lagi bayi perempuan yang diberi nama Sakinah. Empat tahun kemudian, tanggal 8 Juni 1987, keduanya dikaruniai anak ketiga, bayi perempuan diberi nama Munifah. 
Ketiga pelanjut keturunan ini telah menikah dan telah melahirkan keturunan masing-masing. Idrus bin Salim Albaar dikaruniai seorang putra, Sakinah binti Salim dikaruniai dua orang putri, dan Munifah binti Salim memiliki dua orang anak (seorang putra dan seorang putri).

Habib Salim Albaar meninggal dunia tanggal 20 Oktober $2012 \mathrm{M}$. bertepatan dengan tanggal 3 Dzulhijjah $1433 \mathrm{H}$ pada usia 66 tahun. Ia dikebumikan di pekuburan Islam di Ternate di antara keluarga-keluarganya yang telah mendahuluinya.

\section{Pendidikan}

Pendidikan pertama Salim M. Albaar adalah pendidikan informal dalam keluarga, berupa pelajaran membaca Al Qur'an yang diajarkan oleh ayahnya Habib Mustafa Albaar. Setelah mencapai usia sekolah, ia dimasukkan ke sekolah umum, yaitu Sekolah Rakyat Negeri 6 Tahun, Jl. Busaeri Ternate dan tamat 1959/1960. Kemudian melanjutkan pendidikan ke Sekolah Menengah Ekonomi Tingkat Pertama (SMEP) di Ternate dan tamat tahun 1963 setelah menyelesaikan ujian akhir yang diselenggarakan dari tanggal 1 Juni s/d 19 Juni 1963. Selanjutnya ia mengikuti pendidikan SMA di Ternate, tetapi tidak cukup satu tahun karena sementara bersekolah di sekolah ini, ditinggalkannya karena pergi ke Palu untuk memperdalam pelajaran agama di Pesantren $\mathrm{Al}$ Khaerat.

Pada bulan September tahun 1963 Habib Idrus bin Salim al Jufri datang di Ternate bersama enam orang murid seniornya yaitu: Ustadz Muhammad Said Abdullah, Ustadz Muhammad Nur Sulaeman, Ustadz Ibrahim Yahya, Ustadz Yahya H. Adam, Ustadz Ali Al Jufri, dan Ustadz Suyudin. Masyarakat Ternate yang cinta kepada ulama berbondongbondong menjemput dan berkumpul untuk menjumpainya. Kegiatan dakwah yang dilakukan pada beberapa masjid di Ternate selalu ramai diikuti oleh masyarakat.

Penampilan murid-murid beliau membaca Al Qur'an dengan fasih dan lancar, apatah lagi setelah empat orang murid beliau tampil bersamaan membaca Al Qur'an dengan lagu yang indah, merupakan daya tarik tersendiri bagi putra-putra Ternate bersama masyarakat. Karena itu tawaran beliau kepada putra-putra Ternate untuk ikut ke Palu belajar di Al Khairaat yang dipimpinnya bagaikan gayung bersambut. Banyak putra-putra Ternate yang berangkat ke Palu mengikuti beliau pada waktu itu.
Ustadz Muhammad Said Abdullah (73 tahun) mengemukakan bahwa masyarakat sendiri mengirim anak-anaknya sebanyak 40 orang. Beliau berangkat duluan ke Manado dan memerintahkan kepada saya membawa anak-anak itu menyusul dan bertemu di Manado. Bersama 40 orang anak-anak itu, termasuk Salim M. Albaar menyusul sekitar seminggu kemudian. Mula-mula mereka mengikuti pelajaran di tingkat Ibtidaiyah pada kelas-kelas akhir. Mereka di tes lebih dahulu kemudian ditentukan tempatnya di kelas. Salim M. Albaar langsung duduk di kelas V Ibtidaiyah sehingga hanya belajar lebih satu tahun sudah masuk tingkat Tsanawiyah Muallimin 4 tahun. (Wawancara di Ternate tanggal 29 Juni 2013).

Salim M. Albaar menyelesaikan pendidikannya di Madrasah Tsanawiyah Muallimin 4 Tahun Al Khairaat di Palu setelah mengikuti ujian akhir yang diselenggarakan tanggal 25 Oktober s/d tanggal 1 November 1968. Kemudian melanjutkan pendidikannya pada Madrasah Aliyah Muallimin 6 Tahun Al Khairaat di Palu dan dinyatakan lulus setelah mengikuti ujian akhir tanggal 19-21 Desember 1970.

Setelah menyelesaikan pendidikannya pada tingkat Madrasah Aliyah Muallimin 6 Tahun di Pesantren Al Khairaat di Palu, Salim M. Albaar kembali ke Ternate untuk mengabdikan ilmunya di kampong halamannya. Namun kesempatan belajar yang didapatkan di Ternate, terutama untuk mendapatkan legitimasi ijazah negeri, dipergunakan dengan baik. Salim M. Albaar mendaftarkan diri pada Sekolah Persiapan Institut Agama Islam Negeri "Alauddin" di Ternate. Di lihat dari segi jenjang pendidikan, sekolah ini setara dengan tingkat Aliyah yang telah diselesaikannya. Karena itu masa belajar di sekelah ini yang semestinya 2 tahun hanya diikuti 1 tahun, dan dinyatakan lulus setelah mengikuti ujian penghabisan yang diselenggarakan tanggal 10 Desember 1971 s/d 06 Januari 1972.

Pada saat itu belum ada $\mathrm{Al}$ Khaerat di Ternate, dan Al Khaerat di Ternate dibuka dua tahun kemudian. Banyak putra-putra Ternate yang pergi ke Palu bersamanya, namun yang berhasil hanya beberapa orang, termasuk dia. Ia mengikuti jenjang pendidikan di Al Khaerat Palu, mulai tingkat Ibtidaiyah, tingkat Muallimin IV Tahun, dan tingkat Aliyah. Pelajarannya di tingkat Aliyah ini diselesaikan pada tahun 1970. Setelah tamat di Aliyah Al Khaerat, Habib Salim Albaar kembali ke Ternate dan mendaftar pada SP IAIN Ternate, yang setingkat dengan Aliyah sehingga ditempuhnya 
hanya satu tahun dan mendapat ijazah pada tahun 1971.

Habib Salim Albaar melanjutkan pendidikannya ke Fakultas Tarbiyah IAIN Alauddin Cabang Ternate, Jurusan Pendidikan Agama. Dorongan isterinya Fauziah, menjadi motivasi yang tidak kurang pentingnya. Keterlibatan isterinya menjadi mahasiswa bersamanya menambah semangat belajarnya hinggga mampu menyelesaikan studinya pada tingkat sarjana muda setelah menyelesaikan risalahnya berjudul: Faktor-Faktor Penyebab Kemunduran Pendidikan Islam di Desa Pabas Kecamatan Jailolo pada tanggal 20 Desember 1980. Adapun isterinya Fauziah, tertinggal dan tidak berhasil menggondol titel ini karena menjelang KKN ia sakit dan dioperasi di Surabaya sehingga tidak sempat ikut, dan akhirnya dinyatakan Drop Out. Pada tanggal 24 September 1986, Salim M. Albaar menyandang gelar doktorandus (drs.) di perguruan tinggi yang sama, dengan judul skripsi Peranan Madrasah Al Khairaat dalam Pengembangan Pendidikan Islam di Kabupaten Maluku Utara.

\section{Kegiatan Ilmiah yang Diikuti}

Tidak banyak kegiatan ilmiah yang diikuti oleh Salim M. Albaar. Setidaknya hanya dua kegiatan ilmiah saja yang dapat diinventarisasi, yaitu: Pertama, Pelatihan Analisis Peningkatan Pendapatan Asli Daerah dalam kapasitsnya sebagai anggota DPRD Tk II Maluku Utara. Kegiatan ini diselenggarakan oleh Lembaga Pengkajian dan Pendidikan Ekonomi Regional di Yogyakarta pada tanggal 17 - 24 April 1993 dengan hasil Baik; Kedua, seminar Sehari tentang Pemberdayaan Pesantren untuk Transformasi Masyarakat sebagai Peserta. Kegiatan ini diselenggarakan oleh Pusat Pengkajian Islam dan Masyarakat (PPIM) UIN Syarif Hidayatullah Jakarta bekerja sama dengan Kedutaan Besar Jepang di Indonesia pada tanggal 17 Mei 2005 di Jakarta.

\section{Aktivitas Sosial}

Karier Salim M. Albaar dimulai sejak tanggal 1 Maret 1983 saat diangkat sebagai calon pegawai negeri dengan pangkat/golongan Pengatur Muda Tk I (II/b). Selanjutnya ditetapkan sebagai pegawai negeri sipil (PNS) dengan pangkat/golongan yang sama terhitung mulai tanggal 6 April 1984. Keberhasilannya meraih gelar Doktorandus (DRS) pada IAIN Alauddin Cabang Ternate sangat menunjang kariernya sebagai pegawai negeri sipil. Terhitung 1 April 1988, Salim M. Albaar disetujui menempati pangkat / golongan Penata Muda (III/a) melalui penyesuaian ijazah. Empat tahun kemudian, yaitu sejak 1 April 1992, ia dinaikkan menjadi Penata Muda Tk I (III/b). Kegiatannya di bidang politik, sebagai anggota DPRD Kabupaten Maluku Utara tidak menghalangi laju kepangkatannya sebagai PNS, baik sebelum diangkat sebagai PNS maupun sesudahnya karier yang ditekuninya di bidang pendidikan, sebagai guru agama. Tempat pengabdiannya kebanyakan di Madrasah Alkhaerat di Ternate. Di samping itu, Salim M. Albaar pernah dipindahtugaskan ke Kantor Departemen Agama Kabupaten Maluku Utara sebagai Kepala Seksi Kelembagaan Agama Islam. Jabatan ini diembannya kurang lebih satu tahun, yaitu dari tanggal 1 April 1986 s/d tanggal 20 Agustus 1987.

Kariernya sebagai pejabat Kantor Departemen Agama Kabupaten Maluku Utara berakhir dengan cepat karena Salim Albaar memasuki kancah politik praktis atas permintaan Golongan karya pada masa Orde Baru. Pada Pemilihan Umum Tahun 1987 ditetapkan sebagai anggota DPRD Kabupaten Maluku Utara Periode 1987-1992 dari Golkar mewakili unsur ulama. Karier politiknya sebagai anggota DPRD Kabupaten Maluku Utara berlanjut pada periode berikutnya, 1992-1997.

Pengabdiannya di Al Khairaat tidak berhenti saat menjadi anggota DPRD. Buktinya, ia tetap mengajar di Al Khaerat. Kariernya di Al Khaerat dapat dikatakan berjenjang, karena ia pernah Kepala Madrasah Ibtidaiyah, kemudian Kepala Madrasah Tsanawiyah, dan setelah berhenti sebagai anggota DPRD Kabupaten Maluku Utara, ia dipercaya memegang amanat sebagai Kepala Madrasah Aliyah Al Khairaat, yaitu 1998-2005 dan selanjutnya dipercayakan sebagai Ketua Pengurus Harian atau Pimpinan Pondok Pesantren Al Khaerat Ternate pada tahun 2005-2008 berdasarkan Surat Keputusan Pengurus Besar Al Khairaat, nomor 111/A-4/ PBA/2005, tanggal 4 Agustus 2005. Pengabdian terakhirnya dalam kepengurusan $\mathrm{Al}$ Khairaat di Ternate adalah sebagai salah seorang dari 7 orang Dewan Pembina Komisariat Wilayah Al Khairaat Propinsi Maluku Utara Masa Khidmat 2009 - 2014. Penetapan ini berdasarkan Surat keputusan Pengurus Besar Al Khairaat, Nomor 10/A-2/PBA/2009, Tanggal 26 April 2009 M. / 30 Rabiul Akhir $1430 \mathrm{H}$.

Jabatan sebagai pimpinan pondok pesantren dijabatnya setelah pensiun dari PNS tahun 2005. Dengan demikian pengabdiannya di Al Khaerat tetap berlangsung meskipun sudah pensiun sebagai 
PNS. Jabatan terakhir pengabdiannya di bidang agama, selain sebagai Dewan Pembina tersebut, adalah Imam Besar Masjid Al Munawwar Kota Ternate. Ia dipanggil menghadap kepada Yang Maha Kuasa sementara memikul kedua jabatan ini.

Pengabdiannya di $\mathrm{Al}$ Khaerat Ternate tentunya memberikan andil signifikan dalam perkembangan Al Khairaat di Ternate atau Maluku Utara umumnya. Pemerintah Daerah Propinsi Maluku Utara memberikan apresiasi positif yang ditandai dengan pemberian penghargaan sebagai salah seorang dari 12 orang sebagai Tokoh Perintis Pendidikan Propinsi Maluku Utara. Piagam Penghargaan ini berdasarkan Keputusan Gubernur Maluku Utara, Nomor 94/KPTS/MU/2009, Tanggal 1 Mei 2009.

Keterlibatannya di bidang politik prkatis, sebagai anggota DPRD Kabupaten Maluku Utara selama 2 periode, karena desakan, kalau tidak dikatakan paksaan dari pihak Golkar, bukan murni keinginan dia. Ia mengikuti jejak dua orang ulama pendahulunya, yaitu Ustadz Muhammad Nur dan Ustadz Said Abdullah yang menjadi anggota DPRD periode sebelunnya dari unsur ulama dalam lingkungan Golkar.

Ia juga memberikan pengajian sewaktu-waktu di masjid. Ia membina majelis taklim, terutama di Wanita $\mathrm{Al}$ Khaerat selama puluhan tahun. Di Masjid Al Muttaqin, ia dituakan dan ditunjuk sebagai Penasehat/Pembina.

\section{Pendidikan Anak-anaknya.}

Habib Salim bersama isterinya sangat memperhatikan pendidikan anak-anaknya, terutama pendidikan agama. Karena merasa ada kesulitan mengajar sendiri membaca Al Qur'an kepada anak-anaknya sehingga memanggilkan guru mengaji ke rumahnya (guru privat). Untuk pendidikan formal, sampai tingkat sekolah lanjutan pertama anaknya diharuskan masuk sekolah di lingkungan $\mathrm{Al}$ Khaerat, yang mementingkan pendidikan agama melebihi sekolah umum lainnya. Ketika dinilai anak-anaknya mampu menentukan pilihanya sendiri, maka untuk tingkat sekolah lanjutan atas, diberikan kebebasan memilih sesuai minatnya. Anak laki-lakinya memilih SMA tetapi tetap dalam lingkungan Al Khaerat. Setelah tamat melanjutkan kuliahnya di Malang, hanya tidak selesai. Dua anaknya yang perempuan, yang tua masuk sekolah kejuruan menjahit, dan yang bungsu masuk SMA Negeri.

\section{Karya Tulisnya}

Karya tulis H. Salim M. Albaar yang dapat ditemukan saat penelitian ini hanyalah tulisannya berkaitan dengan Habib Idrus Bin Salim al Jufri, pendiri Al Khaerat di Palu. Tulisan ini diberinya judul "Bersama Sang Mujahid (Kenangan pribadi Bersama "Guru Tua"). Berbagai hal dikemukakan dalam tulisan ini berkaitan Sang Guru yang diidolakannya, pribadi dan kelebihan beliau yang patut untuk diteladani serta momen-momen kebersamaannya dengan Sang Gurunya. (Salim Albaar, tth.). Karya tulis lainnya adalah risalah yang ditulisnya sebagai persyaratan untuk memperoleh gelar sarjana muda dan gelar doktorandus.l

\section{PENUTUP}

H. Salim M. Albaar adalah seorang ulama Ternate keturunan Arab yang mewarisi keulamaan dari orang tuanya. Bapaknya Habib Mustafa Albaar tercatat sebagai ulama di Ternate atau Maluku Utara. Kakeknya Habib Muhammad Bin Abd. Rahman Albaar, termasuk ulama terkenal di Ternate yang melahirkan beberapa ulama. Keulamaan yang diperolehnya tidak diperolehnya secara langsung dari ayahnya, tetapi karena usahanya menuntut ilmu agama di Al Khaerat di Palu dari Habib Idrus Bin Salim Al Jufri. Wawasan keilmuannya diperolehnya dari IAIN "Alauddin" Cabang Ternate. Kiprahnya yang utama di bidang pendidikan, yaitu di Al Khairaat di Ternate. Selain sebagai pendidik, ia juga terjun di dunia politik praktis, sebagai anggota DPRD Kabupaten Maluku Utara selama dua periode. Tampilnya sebagai ulama di tengahtengah masyarakat bukan sebagai penceramah tetapi sebagai guru masyarakat.

\section{UCAPAN TERIMAKASIH}

Terima kasih kami haturkan kepada semua pihak yang telah membantu memberikan informasi mendalam terkait ketokohan dan kiprah Salim M. Albaar, kepada keluarga, kerabat, dan koleganya. Secara khusus juga kami sampaikan rasa terima kasih yang sebesar-besarnya kepada redaksi jurnal Al Qalam yang telah memuat tulisan ini. Jazakumullah Khairan Katsiran.

\section{DAFTAR PUSTAKA}

Ahmad, Abd. Kadir. 2008. Ulama Bugis. Cetakan 1. Makassar: Penerbit Indobis Publishing.

Albaar, Salim M. tt. Bersama Sang Mujahid (Kenangan pribadi Bersama "Guru Tua"). 
Tanpa Penerbit.

Anonim. 1986. Al Munjid Fi Allugah wal A'lam. Cetakan 21. Baerut: Darul Masyriq

Darmawijaya. Kesultanan Islam Nusantara. Cetakan 1. Jakarta: Pustaka Al-Kautsar. 2010.

Fakhriati dkk. 2010. Sejarah Sosial Kesultanan Ternate. Cetakan I. Jakarta: Puslitbang Lektur Keagamaan, Badan Litbang dan Diklat, Kementerian Agama RI.

Glasse, Cyril. 2002. Ensiklopedi Islam Ringkas. Ed 1. Cet 3. Jakarta: PT. Raja Grafindo Persada.

Ismuha. 1983. Ulama Aceh Dalam Perspektif
Sejarah. Dalam Taufik Abdullah (ed.). Agama dan perubahan Sosial. Jakarta: CV. Rajawali.

Suprapto, Bibit. 2009. Ensiklopedi Ulama Nusantara (Riwayat Hidup, Karya dan Sejarah Perjuangan 157 Ulama Nusantara. Jakarta: Gelegar Media Indonesia.

Tim Penyusun Kamus Pusat pembinaan dan Pengembangan Bahasa. 1993. Kamus Besar Bahasa Indonesia. Edisi kedua. Cetakan kedua. Jakarta: Balai Pustaka. 1993).

Turmudi, Endang. 2004. Perselingkuhan Kiai dan Kekuasaan. Cetakan I. Yogyakarta: LKiS. 